\title{
Muuntogeenisen ja tavanomaisesti jalostetun perunan rinnakkaisviljelyn kustannukset - analyysi GIS-paikkatietojärjestelmää käyttäen
}

\author{
Jussi Tuomisto ${ }^{1)}$ ja Hanna Huitu ${ }^{2)}$ \\ 1) MTT Taloustutkimus, MTT Ylistaro,61400 YLISTARO jussi.tuomisto@mtt.fi \\ 2) (MTT Taloustutkimus), Menninkäisenrinne 5A3, 02400 Kirkkonummi \\ hanna.huitu@gmail.com
}

Tiivistelmä: Muuntogeenisen perunan viljely edellyttää erilläänpitoa tavanomaisista lajikkeista niin, että lajikkeet eivät pääsisi sekoittumaan. Tämä voidaan toteuttaa muun muassa suojakaista- ja viljelykiertovaatimusten avulla. Erilläänpitovaatimukset aiheuttavat kustannuksia.

Tässä tutkimuksessa selvitetään Gis-paikkatietojärjestelmän avulla, miten perunapeltojen muoto, koko ja etäisyys toisiin perunanpeltoihin sekä viljelykierron järjestäminen vaikuttavat suojakaistavaatimukseen ja sitä kautta maatilojen kustannuksiin. Tällöin otetaan huomioon viljelymaan pinnanmuodostus, alueellinen maatilarakenne sekä ympäröivät rakenteet, kuten metsät, viljelemättömät alueet ja peltojen sijoittuminen. Tutkimuksessa arvioidaan myös mikä olisi sopimustuotannon rooli sopimuslohkojen suunnittelussa ja sopimusten vaikuttavuus viljelijöiden kustannuksiin.

Ammattimainen perunantuotanto on keskittynyt kapealle kaistalle Suomen rannikkoalueille, missä perunanviljelyyn soveltuvat maalajit ovat yleisiä. Ruokateollisuus- ja tärkkelysperuna tuotetaan etupäässä raaka-ainetta hyödyntävien tehtaiden läheisyydessä. Siemenperunantuotanto on pääasiassa keskittynyt Pohjois-Pohjanmaalle.

Ammattimaisessa perunanviljelyksessä monokulttuuri on yleistä. Esimerkiksi Suupohjan alueella 52 \% perunasta viljellään sellaisilla pelloilla, joilla ei vuosikausiin ole viljelty muuta kasvia. Perunapellot sijaitsevat tavallisesti lähempänä talouskeskuksia kuin tilojen muut pellot. Viljelykiertovaatimukset aiheuttavat kaukaisempien peltolohkojen käyttöönottoa perunanviljelykseen.

Ammattimaisen perunantuotannon erityispiirteenä on sopimustuotanto. Sopimusviljelyyn liittyy usein hyvin tiukat lajikevaatimukset sekä yksityiskohtaiset viljelyohjeet, kasvukauden aikainen neuvonta ja tehtyjen viljelytoimenpiteiden seuranta. Geenitekniikan käyttöönotto ja erilläänpidon vaatimukset lisäävät tarjontaketjun verkottumista.

Suomessa Elintarviketurvallisuusvirasto tarkastaa kaikki siemenperunaviljelykset. Lajikesekaantumista on esiintynyt hyvin vähän. Vieraita lajikkeita löytyi vain 0,006 \% vuosien 1998-2004 aikana tarkastetuista 1262000 mukulasta. Sadonkorjuun yhteydessä maahan jääneiden ja seuraavana kasvukautena itäneiden mukuloiden lisäksi lajikesekaantumisia voi tapahtua mukuloiden fyysisenä siirtymisenä sadonkorjuun yhteydessä.

Suojakaistan leveyden kasvaessa perunanviljelyn kustannukset nousevat nopeasti. 10 metrin suojakaista silloin, kun se on perustettu perunalohkon ympärille, nostaa viljelykustannuksia keskimäärin 2,34 senttiä perunakiloa kohti. Yhden vuoden viljelykiertovaatimus nostaa tuotantokustannusta keskimäärin 8,58 senttiä ja viljelyetäisyyden lisääntyminen 0,15 senttiä perunakiloa kohti. Gis-järjestelmän avulla perunalohkojen sijoitus voidaan suunnitella siten, että muuntogeenisen ja tavanomaisen perunan erilläänpitokustannukset muodostuisivat mahdollisimman pieniksi. Sopimustuotannossa Gismenetelmä auttaa myös sopimuksen tarjoajaa suunnittelemaan sopimusmallien rakentamista kullekin sopimustuottajalle.

Avainsanat: Gis-paikkatietojärjestelmä, geenitekniikka, rinnakkaiselo, eristysetäisyys, erilläänpito, tuotantokustannus, kannattavuus, sopimustuotanto, vertikaalinen integraatio. 


\section{Johdanto}

Maa- ja metsätalousministeriön muuntogeenisten kasvien käytöönottoa miettinyt työryhmä antoi 7. joulukuuta 2005 loppuraportin muuntogeenisten viljelykasvien sekä tavanomaisten ja luonnonmukaisen maataloustuotannon rinnakkaiselon mahdollistamisesta Suomessa (MMM 2005). Raportti perustui EU:n komission heinäkuussa 2003 antamaan suositukseen ohjeista kansallisten strategioiden ja parhaiden käytänteiden laatimiseksi eri tuotantomuotojen rinnakkaiseloa varten (EU 2003). Suosituksen periaatteiden mukaan viljelijöiden pitäisi voida viljellä haluamallaan viljelytavalla: muuntogeenisiä, tavanomaisella tuotantotavalla tuotettuja tai luonnonmukaisella tuotantotavalla tuotettuja lajikkeita. Komission mukaan kysymys liittyy myös kuluttajien valinnan mahdollisuuksiin. Jotta Euroopan kuluttajilla olisi todellinen mahdollisuus valita eri tavalla tuotettujen elintarvikkeiden välillä, eivät lainsäädännön uudet jäljitettävyys- ja merkintävaatimukset yksistään riitä, vaan maatalouden on myös kyettävä tuottamaan erilaisia ja eri tavalla tuotettuja hyödykkeitä.

Erityyppisten tuotantomuotojen rinnakkainen käyttö ei ole uusi asia maanviljelyssä. Esimerkiksi kylvösiementen ja perunan tuotannossa on paljon kokemusta puhtaus- ja aitousvaatimusten edellyttämistä viljelykäytänteistä. Yksi keskeisimmistä kysymyksistä on lajikkeiden tai lajien risteytyminen keskenään. Myös luontaisilla esteillä, kuten peltoaukeiden välissä olevilla metsillä ja vesialueilla, on merkitystä niiden kasvilajien geenivirtojen vähentämisessä, joille ei välimaastossa ole luontaisia esiintymiä tai helposti risteytyviä luontaisia sukulaislajeja. Toinen keskeinen tekijä on siementen sekoittumisesta tai jääntikasveista aiheutuva lajikepuhtauden väheneminen viljelyn yhteydessä. Tahatonta sekoittumista voidaan vähentää muun muassa käyttämällä korkealaatuista, sertifioitua kylvösiementä. Työkoneiden puhdistuksella voidaan vähentää siementen kulkeutumista peltojen välillä, ja huolellinen ja suunnitelmallinen korjuu vähentää maahan varisevia siemeniä. Oikein suunniteltu peltojen jälkikäsittely ja rikkakasvien torjunta vähentää jääntikasveja ja tarpeetonta geenivirtaa viljelmällä.

Perunaa lukuun ottamatta keskieurooppalaiset muuntogeeniset viljelykasvit eivät useimmiten sovellu viljelyyn Suomessa ilman jatkojalostusta. Todennäköisesti peruna on ensimmäinen muuntogeeninen viljelykasvi, joka Suomessa otetaan viljelykäytäntöön (Tuomisto 2004). Siksi tämä tutkimus on rajattu tarkastelemaan gm- ja tavanomaisen perunan rinnakkaiselosta aiheutuvia kustannuksia Suomessa.

Maa- ja metsätalousministeriön muuntogeenisten kasvien käytöönottoa miettineen työryhmän antamien ohjeiden ja suositusten mukaan muuntogeenisen aineksen leviämisen estämiseksi on jätettävä 5-10 metrin suojakaista ja gm-perunan jälkeen saa lohkolla viljellä muuta perunaa vasta vähintään yhden välivuoden kuluttua, ja siemenenä on tällöin käytettävä sertifioitua siemenperunaa (MMM 2005)

Tässä tutkimuksessa selvitetään Gis-paikkatietojärjestelmän avulla, miten perunapeltojen muoto, koko ja etäisyys toisiin perunanpeltoihin vaikuttavat suojakaistavaatimukseen ja sitä kautta maatilojen kustannuksiin. Tällöin otetaan huomioon viljelymaan pinnanmuodostus, viljelykierto ja maatilarakenne sekä ympäröivät rakenteet, kuten metsät, viljelemättömät alueet ja peltojen sijoittuminen. Tutkimuksessa arvioidaan myös mikä tulisi olemaan sopimustuotannon rooli sopimuslohkojen suunnittelussa ja sopimusten vaikuttavuus viljelijöiden kustannuksiin.

\section{Aineisto ja menetelmät}

Tämän tutkimuksen tutkimusaineisto koostuu Gis-paikkatietojärjestelmän karttaaineistosta, Maa- ja metsätalousministeriön tietohallintakeskuksen (TIKE) lohkotietorekisteristä, Elintarviketurvallisuusviraston (Evira) siemen- ja luomuvalvontayksikön (Silu) tilastoista sekä kannattavuuskirjanpitotilojen kannattavuusseurannasta. Taulukossa 1 on esitettynä Eviran siementarkastusaineisto vuosilta 1998-2004. 
Taulukko 1. Vieraiden lajikkeiden esiintyminen siemenperunassa 1998-2004 (Evira)

\begin{tabular}{lrr}
\hline & $\begin{array}{c}\text { Kaikki } \\
\text { siemen- }\end{array}$ \\
peruna & Perussiemen \\
Tutkimusaineisto & 9203 & 3139 \\
\hline Tutkimusala (hehtaaria) & 2524 & 1225 \\
Testattuja lohkoja (kappaletta) & 1262000 & 612500 \\
Tutkittujen mukuloiden määrä (kpl) & & \\
Tulokset & 256 & 233 \\
Vieraita lajikkeita (kpl) & $0.020 \%$ & $0.038 \%$ \\
\% kokonaismäärästä & 76 & 53 \\
- Outlier (180 väärää lajiketta yhdellä tilalla) & $0.006 \%$ & $0.009 \%$ \\
\% kokonaismäärästä & & \\
& 50 & 37 \\
Niiden lohkojen lukumäärä, joilta löytyi vieraita lajikkeita (kpl) & 10 & 2 \\
joista perunaa oli viljelty edellisenä vuonna (sama lajike) (kpl) & 35 & 31 \\
joista perunaa oli viljelty kolme vuotta aikaisemmin (kpl) & 56.43 & 24.97 \\
Keskimääräinen viljelyetäisyys (m) & 3.65 & 2.56 \\
Keskimääräinen lohkokoko (ha) & &
\end{tabular}

Perunapeltojen etäisyyksien, suojakaistatarpeen ja viljelykierron kartoittamista varten Suomi jaetaan seitsemään perunantuotantoalueeseen. Kuvan 1 kartassa on esitetty alueiden sijainti. Karttaan merkityillä seitsemällä alueella viljellään noin puolet Suomessa tuotetusta perunasta. Taulukossa 2 on esitetty, miten pinta-alat jakautuvat kullakin alueella.

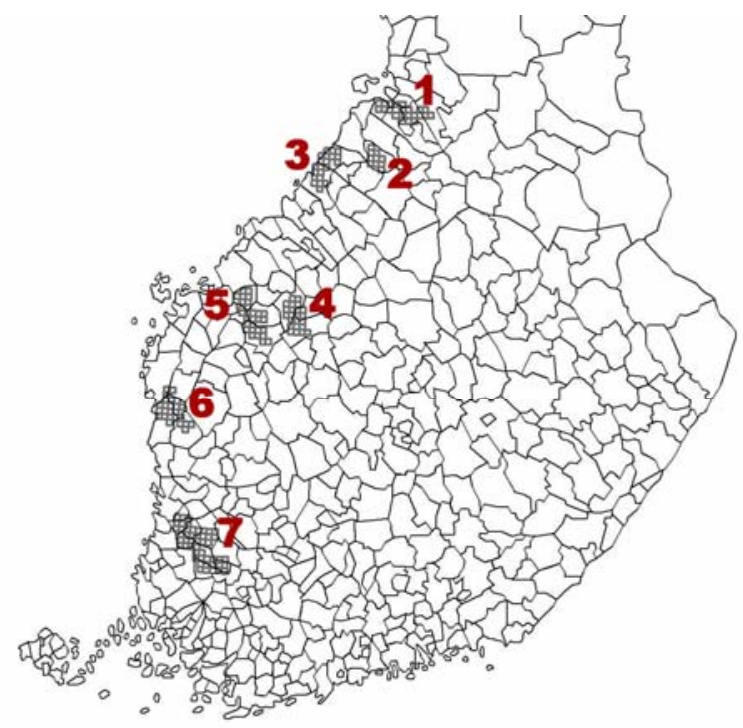

Kuva 1. Tarkasteluun valittujen perunapeltojen sijainti Suomessa

Paikkatietojärjestelmän avulla selvitetään kultakin alueelta perunalohkojen sijoittuminen toisiinsa nähden, suojakaistavaatimus huomioiden luontaiset suojakaistat, perunapeltojen muoto ja lajikejakauma lohkoilla, monokulttuurin harjoittamisen yleisyys ja alueellinen keskittyneisyys sekä perunapeltojen etäisyys maatilojen talouskeskuksista. Lohkoja tarkastellaan ruutu kerrallaan peruskartan neljänneksinä (5 km x 5 km).

Kuvan 2 oikeanpuoleisessa kuvassa on esitetty neljä maatilaa. Pisteet kuvassa ovat maatilojen talouskeskuksia ja reunustettuna ne peltolohkot, joilla maatilat viljelevät perunaa. Lohkojen suojakaistat on merkitty kuvaan punaisella. Isoilla neliönmuotoisilla lohkoilla, joilla on olemassa luonnollisia suojavyöhykkeitä, voidaan päästä pienilläkin suojakaistatarpeilla, 
kun taas pitkillä ja kapeilla lohkoilla suojakaistavaatimus voi tehdä viljelyn lähes mahdottomaksi.

Taulukko 2. Viljelyalueiden jakautuminen tarkasteltavilla karttalehdillä

\begin{tabular}{|c|c|c|c|c|c|c|c|c|}
\hline ALUE & $\begin{array}{l}\text { Kartta- } \\
\text { lehden } \\
\text { neljän- } \\
\text { neksiä } \\
\text { kpl }\end{array}$ & $\begin{array}{l}\text { Kokonais- } \\
\text { pinta-ala } \\
(\mathrm{km} 2)\end{array}$ & $\begin{array}{l}\text { Josta maa- } \\
\text { alue } \\
(\mathrm{km} 2)\end{array}$ & $\begin{array}{l}\text { Metsää } \\
(\mathrm{km} 2)\end{array}$ & $\begin{array}{l}\text { Peltoa ja } \\
\text { laidunta } \\
\text { (km2) }\end{array}$ & $\begin{array}{l}\text { Tukea } \\
\text { saava } \\
\text { peltoala } \\
(\mathrm{km} 2)\end{array}$ & $\begin{array}{l}\text { Peruna- } \\
\text { ala }(\mathrm{km} 2)\end{array}$ & $\begin{array}{l}\text { Perunan } \\
\text { osuus }\end{array}$ \\
\hline 1 & 23 & 619,3400 & 585,7700 & 230,1600 & 291,5800 & 275,1300 & 14,6530 & $5,3 \%$ \\
\hline 2 & 10 & 250,0100 & 249,4000 & 153,5900 & 26,2500 & 36,0000 & 0,0969 & $0,3 \%$ \\
\hline 3 & 21 & 525,2100 & 459,8300 & 323,8600 & 107,6900 & 110,9800 & 12,9683 & $11,7 \%$ \\
\hline 4 & 22 & 550,4000 & 417,2700 & 264,2400 & 171,7600 & 131,7000 & 10,0776 & $7,7 \%$ \\
\hline 5 & 29 & 725,6700 & 719,8200 & 302,8800 & 314,0500 & 328,3700 & 20,2336 & $6,2 \%$ \\
\hline 6 & 25 & 626,1800 & 617,3400 & 396,5200 & 143,4400 & 146,8400 & 33,7653 & $23,0 \%$ \\
\hline 7 & 48 & 1237,5700 & 1173,5700 & 609,3200 & 422,6900 & 421,5100 & 32,6734 & $7,8 \%$ \\
\hline TOTAI & & 4534,3800 & 4223,0000 & 2280,5700 & 1477,4600 & 1450,5300 & 124,4681 & $8,6 \%$ \\
\hline
\end{tabular}

Vasemmanpuoleisessa kuvassa on esitetty erään maatilan perunalohkojen sijainti Kristiinankaupungissa, Suomen tiheimmällä perunanviljelyalueella, jossa pitkät ja kapeat peltolohkot ovat yleisiä Kuvassa on esitetty vaaleanpunaisella tarkasteltavan tilan hallinnassa olevat peltolohkot, tummanpunaisella punaisella ne peltolohkot jossa kyseisellä tilalla on perunaa viljelyksessä tarkasteltavana kasvukautena sekä siniharmaalla ne naapuritilojen peltolohkot, joilla viljellään tai saatetaan viljellä perunaa. Viljelijällä on epätäydellinen informaatio siitä, mitä naapurit viljelevät. Keltaisella on merkitty ne peltolohkot, joilla ei viljelty lainkaan perunaa. Punainen piste on tarkasteltavan tilan talouskeskus.
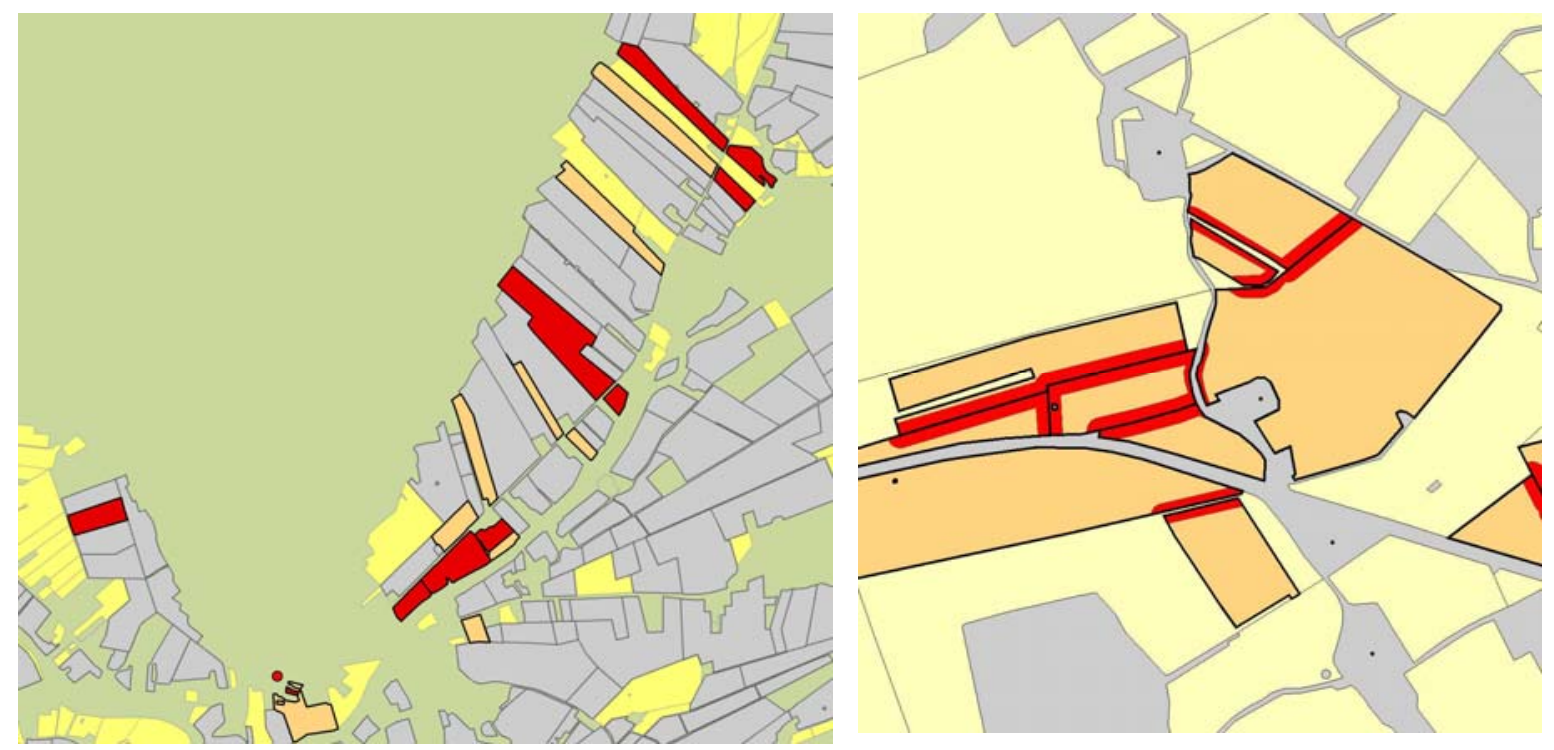

Kuva 2. Peltolohkojen sijoittuminen (vas.) ja Suojakaistavaatimukset (oik.) eräillä lohkoilla

Taulukossa 3 on esitetty suojakaistatarve Suupohjan alueella. Jos suojakaistatarve on 5 metriä, suojakaistat tarvitsevat koko alueella yhteensä 74,10 hehtaaria. Osuus olisi 2,2 \% alueen peruna-alasta. Tiloja, joilla suojakaistatarvetta ilmenisi, olisi 607 kappaletta, maksimi suojakaista-ala olisi 0,68 hehtaaria ja maksimiosuus pinta-alasta $50 \%$. Jos suojakaistatarve on 20 metriä, suojakaistan osuus nousisi moninkertaiseksi, joillakin peltolohkoilla jopa koko ala hukkuisi pelkästään suojakaistaan. 
Taulukko 3. Suojakaistatarve Suupohjan alueella (Alue 6)

\begin{tabular}{|c|c|c|c|c|c|c|c|}
\hline & На & Osuus & Kpl & $\begin{array}{l}\text { Keskiarvo } \\
\text { (ha) }\end{array}$ & $\begin{array}{l}\text { Keskihajonta } \\
\text { (ha) }\end{array}$ & $\begin{array}{l}\text { maksimi } \\
\text { ala (ha) }\end{array}$ & $\begin{array}{c}\text { maksimi- } \\
\%\end{array}$ \\
\hline Kokonaisala & 14684,3 & & & & & & \\
\hline Peruna-ala & 3376,53 & $23 \%$ & & & & & \\
\hline uojakaistatarve & & & & & & & \\
\hline $5 \mathrm{~m}$ & 74,10 & $2,2 \%$ & 607 & 0,12 & 0,10 & 0,68 & $50 \%$ \\
\hline $10 \mathrm{~m}$ & 163,84 & $4,9 \%$ & 692 & 0,24 & 0,21 & 1,34 & $96 \%$ \\
\hline $20 \mathrm{~m}$ & 357,00 & $10,6 \%$ & 735 & 0,49 & 0,40 & 2,73 & $100 \%$ \\
\hline
\end{tabular}

Taulukossa 4 on paikkatietojärjestelmän avulla esitetty perunanviljelyksen viljelykierto tarkasteltavilla alueilla. Peruslohkoja, joilla perunaa viljellään on yhteensä 18117 hehtaaria. Peruna-ala on 12468 hehtaaria, eli 69 \%. HG-alueella monokulttuurin osuus on selvästi pienempi kuin muilla alueilla. Yksi merkittävä syy tähän on siemenperunantuotannon keskittyminen HG-alueelle. Siemenperunantuotannon asetukset jo edellyttävät kasvinvuorotusta. Suupohjassa, jossa on tihein perunantuotannon keskittymä, monokulttuurin osuus on suurin: 52 prosentilla perunapelloista viljellään joka vuosi perunaa. Perunapelloista 49 prosentilla perunaa on yli puolet lohkojen pinta-alasta ja perunan osuus tällaisilla lohkoilla on keskimäärin 95 prosenttia.

Taulukko 4. Viljelykierron toteutuminen tarkasteltavilla alueilla

\begin{tabular}{|c|c|c|c|c|c|c|c|c|c|}
\hline Alue & Taajuu & vuosic & peruna & 5 vuoc & en aika & $\begin{array}{l}\text { na (ha, \%) } \\
\text { Peltoala, } \\
\text { joilla } \\
\text { perunaa } \\
\text { vähintään } \\
\text { kerran } \\
\text { viidessä } \\
\text { vuodessa }\end{array}$ & $\begin{array}{l}\text { yli } \\
50 \% \\
\text { peru- } \\
\text { naa } \\
\end{array}$ & $\begin{array}{l}\text { Osuus } \\
\text { koko- } \\
\text { nais- } \\
\text { peruna- } \\
\text { alasta } \\
\end{array}$ & $\begin{array}{l}\text { Perunan } \\
\text { osuus } \\
\text { perus- } \\
\text { lohkosta }\end{array}$ \\
\hline \multirow[t]{2}{*}{1 HG-alue } & 818 & 980 & 552 & 302 & 339 & 2992 & 215 & $7 \%$ & $63 \%$ \\
\hline & $27 \%$ & $33 \%$ & $18 \%$ & $10 \%$ & $11 \%$ & & & & \\
\hline \multirow[t]{2}{*}{2 Vihanti } & 6 & 2 & 3 & 1 & 5 & 18 & 4 & $22 \%$ & $77 \%$ \\
\hline & $34 \%$ & $12 \%$ & $17 \%$ & $8 \%$ & $29 \%$ & & & & \\
\hline \multirow[t]{2}{*}{3 Pyhäjoki-Kalajoki } & 187 & 328 & 237 & 207 & 755 & 1715 & 714 & $42 \%$ & $94 \%$ \\
\hline & $11 \%$ & $19 \%$ & $14 \%$ & $12 \%$ & $44 \%$ & & & & \\
\hline \multirow[t]{2}{*}{4 Järvi-Pohjanmaa } & 260 & 160 & 246 & 285 & 531 & 1482 & 514 & $35 \%$ & $97 \%$ \\
\hline & $18 \%$ & $11 \%$ & $17 \%$ & $19 \%$ & $36 \%$ & & & & \\
\hline \multirow[t]{2}{*}{5 Lapuan seutu } & 558 & 580 & 597 & 497 & 875 & 3108 & 803 & $26 \%$ & $92 \%$ \\
\hline & $18 \%$ & $19 \%$ & $19 \%$ & $16 \%$ & $28 \%$ & & & & \\
\hline \multirow[t]{2}{*}{6 Suupohja } & 443 & 475 & 552 & 582 & 2212 & 4264 & 2104 & $49 \%$ & $95 \%$ \\
\hline & $10 \%$ & $11 \%$ & $13 \%$ & $14 \%$ & $52 \%$ & & & & \\
\hline \multirow[t]{2}{*}{7 Kokemäen alue } & 707 & 646 & 657 & 705 & 1824 & 4538 & 1549 & $34 \%$ & $85 \%$ \\
\hline & $16 \%$ & $14 \%$ & $14 \%$ & $16 \%$ & $40 \%$ & & & & \\
\hline \multirow[t]{2}{*}{ Yhteensä } & 2979 & 3171 & 2845 & 2581 & 6541 & 18117 & 5902 & $33 \%$ & $90 \%$ \\
\hline & $16 \%$ & $18 \%$ & $16 \%$ & $14 \%$ & $36 \%$ & & & & \\
\hline
\end{tabular}

Kaikkien peltolohkojen keskietäisyys talouskeskukseen on keskimäärin 2378 metriä. Perunapeltojen keskietäisyys on 1973 metriä ja monokulttuurilohkojen etäisyys 1623 metriä. Perunanviljely on keskittynyt talouskeskusten läheisyyteen. Perunalohkot, muun muassa useiden kasvinsuojeluruiskutusten ja sadonkorjuussa suurten kuljetusmäärien takia, on pyritty perustamaan lähemmäksi talouskeskusta ja näin on alennettu kuljetus- ja työkustannuksia. 


\section{Tulokset ja tulosten tarkastelu}

Tutkimuksessa tarkasteltiin Eviran tarkastusaineiston perusteella lähimmän perunapellon yhteyttä vieraiden lajikkeiden esiintymiseen niillä lohkoilla, joilla etäisyys on alle 20 metriä. Tälle yhteydelle laskettiin epäparametrinen Spearmanin korrelaatiokerroin. Korrelaatiokerroin on hyvin pieni $(-0,03)$, eikä tilastollisesti merkitsevä $(\mathrm{p}=0,15)$. Tämä siis kertoo, että alle 20 metrin etäisyyksillä ei havaita tilastollisesti merkitsevää yhteyttä etäisyyden ja vieraiden lajikkeiden esiintymisen välillä. Myöskään edellisten vuosien viljelyhistorialla $(0,05)$ ja peltolohkojen koolla $(-0,06)$ ei ollut tilastollisesti merkitsevää vaikutusta siihen, löytyikö perunapellolta vieraita lajikkeita.

Kannattavuuskirjanpitoon perustuvien tilamallilaskelmien mukaan ruokaperunantuotannon tuotantokustannus vuonna 2006 oli keksikokoisella päätoimisella 37.50 hehtaarin tilalla 25,93 senttiä/kg (vaihteluväli 25,21-30,31). 10 metrin suojakaista silloin, kun se on perustettu perunalohkon ympärille, nostaa tuotantokustannusta keskimäärin 2,34 senttiä/kg.

Suojakaistojen tarve vaihtelee alueellisesti. Sellaisilla alueilla jossa perunantuotannon osuus on vähäisempi, peltolohkot ovat säännöllisen muotoisia ja ympärillä on luonnollisia suojakaistoja, suojakaistojen tarve on vähäisempi. Suupohjan alueella, jossa perunantuotanto on keskittyneempää, suojakaistojen tarve on suurempi ja samalla se aiheuttaa enemmän kustannuksia viljelijöille. Kuvio 1 esittää suojakaistavaatimusten aiheuttamat kustannukset ruokaperunantuotannossa. Kuviossa on esitettynä todellisesta suojakaistojen perustamistarpeesta perunakiloa kohti aiheutuvat lisäkustannukset Suupohjan (alue 6) ja High Gradealueen (alue 1) perunantuotannossa. Esimerkiksi 10 metrin suojakaista High Grade-alueella aiheuttaisi 0,35 (vaihteluväli 0,10-0,48) sentin (0,6 \%) lisäkustannuksen perunakiloa kohti kun taas Suupohjan alueella lisäkustannus olisi 0,37 senttiä (1,4\%) (Vaihteluväli 0,25-0,84). Perunantuottajat eivät välttämättä tiedä mitä naapuritila aikoo viljellä viereisellä peltolohkolla Geenitekniikan käyttöönotto voi lisätä naapuritilojen kasvinvuorotusta siten, että hekin voivat alkaa viljellä perunaa sellaisilla lohkoilla, joissa eivät ole aikaisemmin viljelleet.

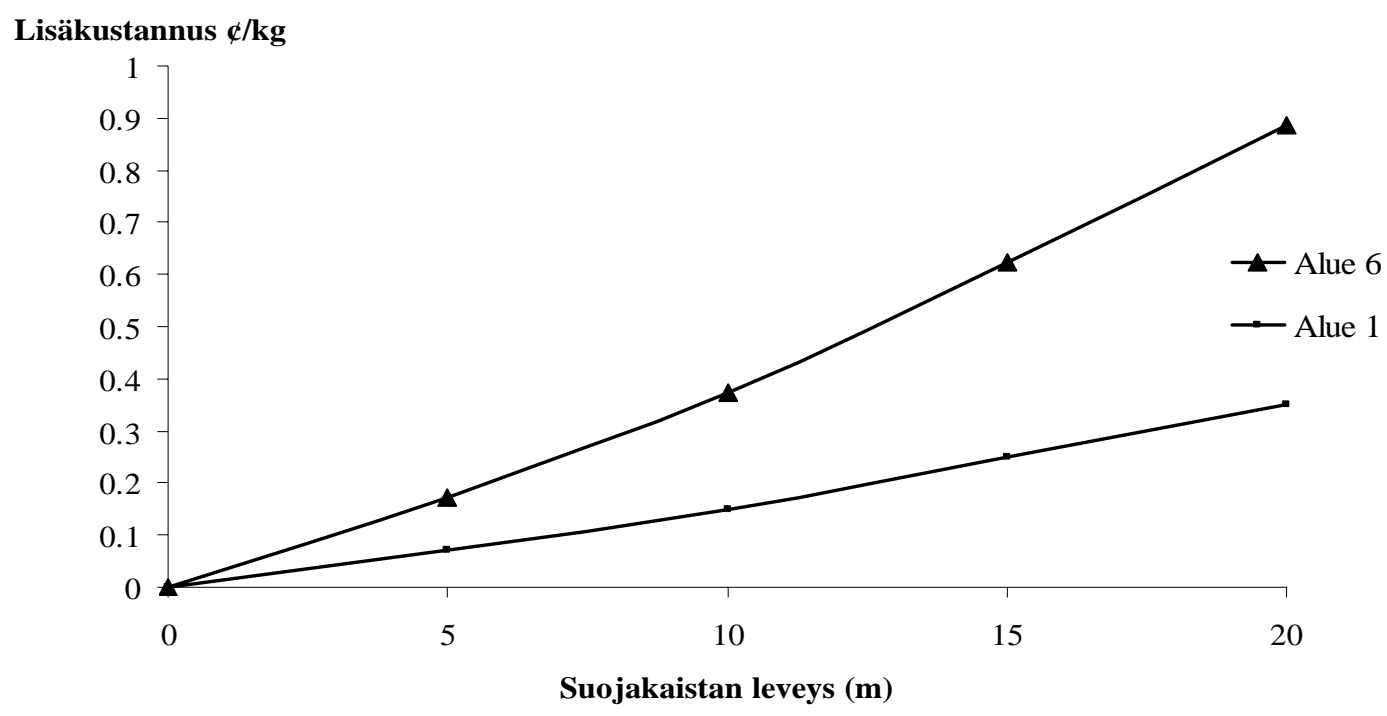

Kuvio 1. Suojakaistan leveyden vaikutus lisäkustannuksiin

Yhden kasvukauden viljelykiertovaatimus siten, että kasvulohkolla viljellään viljaa välikasvina nostaa ruokaperunan tuotantokustannusta keskimäärin 8.58 senttiä/kg (24.9\%) (vaihteluväli 4,53-11,37 snt/kg).

Kun perunantuotanto on usein keskittynyt lähemmäksi talouskeskuksia, uusien talouskeskuksista etäämmällä olevien peltolohkojen käyttöönotto lisää kuljetuskustannuksia. 
Jos perunaa viljeltäisiin samalla etäisyydellä kuin keskimäärin muita kasveja nostaisi se perunantuotannon kustannusta 0,15 senttiä/kg (0,6 \%) (Vaihteluväli 0,1 - 0,48 senttiä/kg).

\section{Johtopäätökset}

Viljelykiertovaatimusta ei ole, jos viljelijä jatkaa gm-perunan viljelyä aina samalla peltolohkolla. Jos viljelijä haluaa samalla lohkolla viljellä gm-perunan jälkeen muuta perunaa, on pidettävä välivuosi perunanviljelyssä. Viljelykiertovaatimus on kallis toteuttaa perunantuotannossa. Jos on kerran aloittanut gm-perunan viljelyn, ei ole enää taloudellisesti kannattavaa palata samalla lohkolla tavanomaisten lajikkeiden viljelyyn. Tämä antaa kilpailuedun gm-perunan viljelylle. Toisaalta alkuvaiheessa uponneet kustannukset ja epävarmuus (riski) voivat vähentää viljelijöiden kiinnostusta ottaa käyttöön gm-lajikkeita.

Viljelykierron lisääminen aiheuttaa kaukaisempien lohkojen käyttöönottoa ja siten kuljetuskustannukset lisääntyvät. Perunantuotannossa on ominaista esimerkiksi viljanviljelyyn verrattuna suuremmat satomäärien kuljetukset ja useat torjunta-aineruiskutuskerrat kasvukauden aikana. Siksi perunantuotanto on ollut muuta viljelystä keskittyneempää talouskeskusten läheisyyteen.

10 metrin suojakaista on liian kallis toteuttaa, varsinkin kun tilastojen mukaan ei ole merkitsevää yhteyttä etäisyyden ja vieraiden lajikkeiden esiintymisen välillä. Suojakaistavaatimus vaikeuttaa gm-lajikkeiden kilpailukykyä, myös tuontituotteita kohtaan.

Gm-perunan käyttöönotto lisää tarjontaketjun verkottumista. Suomessa on nyt jo viitteitä perunantuotannon verkottumisesta. (Tuomisto 2007). Lajike-edustajalla tai perunan viljelyttäjällä, joka on mahdollisesti iso toimija markkinoilla, on yksittäistä viljelijää paremmat mahdollisuudet muun muassa käyttää Gis-järjestelmää apuna peltolohkojen sijoittelussa ja samalla se kykenee alentamaan rinnakkaiselosta aiheutuvia kustannuksia. Viljelyttäjä voi tätä menetelmää hyväksikäyttäen myös "ulosmitata” osan hyödyistä itselleen.

Erilläänpitokustannuksia voidaan alentaa erilaisten sopimusten avulla. Viljelijällä on epätäydellinen informaatio siitä, mitä naapuritilat tekevät. gm-perunaa viljelevä voi kuitenkin aina sopia naapurien kanssa suojakaistojen jättämisestä tai siitä, että naapuri ei laita perunaa viereiselle lohkolle. Viljelijä voi sopia myös naapurin kanssa yhteisen viljelykierron järjestämisestä siten että erilläänpidon kustannukset minimoituisivat. Viljelysopimuksia ja suunnitelmia voi tehdä myös kolmas osapuoli, jolla on Gis-järjestelmä apuna peltolohkojen viljelykiertoa ja suojakaistoja suunniteltaessa. Sopimusten tekeminen kuitenkin aiheuttaa transaktiokustannuksia ja sopimusten teossa voi joku sopijaosapuolista (viljelijä, naapuri tai kolmas osapuoli) kerätä itselleen kaiken uudesta teknologiasta saatavan hyödyn. Mitä suuremmat erilläänpitovaatimukset ovat, sitä suuremmat kustannukset muodostuvat kotimaiselle perunantuotannolle mukaa lukien gm-, tavanomaisen tai luonnonmukaisesti tuotetun perunan. Tällöin tuontiperuna tai -perunatuotteet, myös muuntogeeniset, saavat kilpailuedun markkinoilla. Perunan tuontikustannus esimerkiksi Ruotsista on 1,5-3 senttiä/kg.

\section{Kirjallisuus}

EU 2003. Komission suositus, annettu 23 päivänä heinäkuuta 2003, ohjeista kansallisten strategioiden ja parhaiden käytänteiden laatimiseksi muuntogeenisten viljelykasvien sekä tavanomaisen ja luonnonmukaisen maataloustuotannon rinnakkaiseloon (2003/556/EY). http://honeybee.helsinki.fi/esgemo/raportit/suositus.pdf

MMM 2005. Muuntogeenisten viljelykasvien sekä tavanomaisen ja luonnonmukaisen maataloustuotannon rinnakkaiselon mahdollistaminen Suomessa. Loppuraportti. Maa- ja metsätalousministeriö. Rinnakkaiselon ohjaustyöryhmä. Työryhmämuistio MMM 2005:16. 44 s.

Tuomisto, J. 2007 Contract production as a method to reduce welfare loss caused by market uncertainty of seed potato, Agricultural and Food Science vol. 16. p. 3-16, 2007.

Tuomisto, J. 2004. Benefits and costs of the first wave of gene technology: A case study on potato in Finland. A paper presented at the 8 th ICABR International Conference on Agricultural Biotechnology: International Trade and Domestic Production Ravello (Italy), July 8 - 11, 2004. 19 p. 